\title{
Balla Zsuzsa[1]: Lehetséges kutatási módszerek a közbeszerzésben - résztvevő megfigyelés és interjú -
}

Debreceni Jogi Mühely, 2009. évi (VI. évfolyam) 2. szám (2009. április)

A közbeszerzési eljárások kapcsán számos kutatási módszer tünik kézenfekvőnek. A közbeszerzés vizsgálatakor az első vizsgálandó empíria maga a Közbeszerzési eljárásokról szóló törvény[2]. A törvény vizsgálata történhet egyszerüen egy tartalomelemzéssel, de egyfajta forráskritikai módszerrel is. A tartalomelemzéstől - a törvény esetében eltekintenék, hiszen nem jutnék túlságosan tudományos végeredményhez. A tartalomelemzés módszerét inkább a témában íródott müvek esetében alkalmazom. A klasszikus irodalom feldolgozásnak a szerepe az, hogy a főbb elméleti kereteket megtaláljam, illetve alaposabban megismerkedjek a témával. A tartalomelemzés módszere segítséget ad egy szöveg rejtett üzeneteinek a kereséséhez is.

Módszeremül választhatom a statisztikai eredmények elemzését. A Központi Statisztikai Hivatal végez felméréseket a közbeszerzési eljárásokkal kapcsolatosan. Például az értékhatárokkal, eljárás fajtákkal és az összértékkel, illetve a jogsértést megállapító és bírságot kiszabó határozatokkal kapcsolatban. A legutóbbival szemben merül fel néhány hiányosság. Ezek az adatok csak azokra az eljárásokra vonatkoznak, amelyekben napfényre került a szabálytalanság. Csak becslések vannak arra nézve, hogy az eljárások hány százalékában van valamilyen kisebb vagy nagyobb szabálytalanság. A statisztikai adatokat érintően fontos megemlíteni azt a tényt, hogy a Központi Statisztikai Hivatal szervezeti felépítése miatt az adatok vizsgálata megyei szinten történik. Az adatok összehasonlítása lehetetlen regionális vagy térségi szinten. Ezek alapján torzítást mutathat a kapott eredmények tekintetében.

Kutatási módszerem lehet a kérdőíves módszer. Egy jól megszerkesztett és jó mintamerítésü kérdőív hasznos adatokat szolgáltathat a kutatáshoz és akár magához a hipotézisalkotáshoz. A kérdőíves módszer használatánál tisztában kell lenni azzal, hogy pénz és időigényes kutatás. Számolni kell azzal is, hogy lehetséges, hogy nem minden megkérdezett fog válaszolni. Lehet készíteni egy kisebb kérdőívet is, illetve valamilyen szelektálással kiválogatni azokat, akiket megkérdezek. Az így kapott adatokat azonban óvatosan kell felhasználni, mert a kutatás eredménye biztos, hogy nem reprezentatív.

Általam már használt és továbbra is használni kívánt módszer az interjúkészítés. Az interjúzás előnyeként említhető meg, hogy a technika elsajátítása nem olyan nehéz. Az interjúkészítéssel kapott eredményekkel szintén alátámaszthatjuk a témaválasztásunkat és a kutatásunkat. Az interjúkészítés egyik fajtája a brainstorming. Fókuszcsoportos interjút készíthetek például a közbeszerzésbe bekapcsolódott vállalkozókkal és az interjú a tapasztalataikra illetve az ötleteikre irányulna.

Az interjúzás mellet párhuzamosan használható a megfigyelés módszere. A megfigyeléssel az interjúalany metakommunikációja sok mindent elárulhat. Akár azt is, hogy nem a valós érzelmeit mondja, illetve az egész témával kapcsolatos véleményét is. Az inerjúkészítést és a megfigyelést már alkalmaztam a kutatásom során, jogi segítségnyújtásomat felajánlva cserébe segítséget kaptam debreceni kis- és nagyvállalkozóktól.

Módszerem lehet továbbá az esettanulmányok elemzése, illetve módszerem lehet egy esettanulmány elkészítése. Az esettanulmányban egy vagy több jogeset is bemutatható. A jogesetek bemutatásával szintén alátámasztható a kutatás aktualitása. A megfelelő jogestek kiválasztásával a statisztikai, kérdőíves és interjús módszer alkalmazásával kapott eredmények is alátámaszthatóak. 
A közbeszerzéseket alapvetően a tartalomelemzés és a statisztikai módszerével közelítik meg, de szerintem ez kevés a téma alapos kutatásához, így a felsorolt módszerek együttes alkalmazására van szükség a legjobb kutatási módszer, és így a legjobb kutatatási eredmény eléréséhez.

Dolgozatomban bemutatom, hogy hogyan alkalmaztam a résztvevő megfigyelést pontosan egy adott cégnél, milyen kiindulási feltételek voltak a terepkutatás során, milyen erősségeit és gyengeségeit tapasztaltam, illetve milyen eredményre jutottam. A megfigyelés módszerét némiképp ötvöztem az interjúkészítés technikájával. Egy rövid interjú alá vettem a cég azon dolgozóit, akik bármilyen szinten is, de kapcsolatba kerülnek a közbeszerzéssel. Fontosnak tartottam, hogy e két technikát valahol összekapcsoljam, mert így valósághübb képet kaphatunk. Egy egyszerü megfigyelés során nem biztos, hogy felszínre kerülnek a valódi gondolatok és érzelmek, nem derül ki egyértelmüen a véleményük. Sőt, mivel résztvevő megfigyelést folytattam, így akaratlanul is, ha nem is befolyásoltam, de kihatással voltam a döntéseikre. Az interjú azonban lehetősét adott arra, hogy megkérdezzem az eddigi tapasztalataikat.

A megfigyelés módszerének az a nagy előnye, hogy segítségével a jelenségeket a természetes közegükben figyelhetjük meg. Vannak olyan dolgok, amelyek jól kutathatóak a gyakorlat vizsgálata nélkül, de a közbeszerzés rendszere nem ilyen. Sőt a közbeszerzéssel kapcsolatos anomáliák vizsgálata kizárja a csak „laboratóriumi vizsgálatok” lehetőségét. Mindenképpen olyan kutatási téma ez, amely terepkutatás tárgya kell hogy legyen. Ráadásul - mint már említettem - a terepen végzett közvetlen megfigyeléskor a kommunikáció olyan finom részleteit és más olyan jelenségeket is észrevehetünk, amelyeket másként nem látnánk elöre és ezáltal nem is tudnánk mérni.[3]

A megfigyelés módszerében a megfigyelö több szerep közül is választhat. A megfigyelés során marad a háttérben és a megfigyeltek nem is sejtik, hogy ők egy kutatási módszer alanyai. Másik esetben azonban a megfigyelő felfedi kilétét és így próbál kutatást végezni. Én is ekképp cselekedtem. Alapvetően mindkét technikával szemben hozhatóak fel kritikák. Abban az esetben, amikor a megfigyelö nem árulja el, hogy ő tudományos kutatást végez, ez valahol etikai problémát vet fel. Hiszen nem feltétlenül etikus dolog megtéveszteni a másikat. Ezzel a problémakörrel már több szakmai csoport is foglalkozott. Azonban elmondható, hogy a kutató így érvényesebb és megbízhatóbb adatokhoz fog jutni, és hogy az alanyok természetesebben viselkednek és őszintébbek, ha nem tudják a kutatóról, hogy kutatást végez.[4]

A másik esetben, amikor a megfigyelőről tudják, hogy megfigyelést végez, szintén támadható kritikával. Könnyen előfordulhat, hogy a megfigyelő teljesen résztvevő válik, és már nem tudja annyira objektíven szemlélni az eseményeket, és így sokat veszít a tudományos távolságtartásból. Tehát a különféle helyzetek eltérő szerepet követelnek meg a tudományos kutatásra vágyó kutatótól. Nincs könnyü helyzetben a kutató, hogy melyiket válassza, így saját döntésétöl függ. A döntésnél azonban mind a módszertani, mind az etikai megfontolásokat fegyelembe kell vennie a kutatónak.[5]

A döntésemnél szem előtt tartva az etika fontosságát és a kellő tudományosságot, a két véglet közötti szűk mezsgyén igyekeztem maradni. Beavatva a körülöttem lévőket a megfigyelésbe, de kellő távolságból szemlélődve. A tudományos érdek megköveteli ezt a kettősséget.

A kutatás során azt figyeltem meg, hogy a cég hogyan viszonyul a közbeszerzés egészéhez és annak részfolyamataihoz. Továbbá milyen fajta közbeszerzési eljárásokra pályáznak, milyen eredményekkel zárulnak mindezek. Illetve a közbeszerzési rendszerrel kapcsolatos véleményeiket, tapasztalataikat figyeltem. Kutatásom során végig kísértem az egész folyamatot, a közbeszerzési felhívás megtalálásától az esetleges pótmunka elvégzéséig. A 
kutatás érdekességeként emelném ki, hogy külön figyeltem meg azokat az embereket, akik más-más szakaszában találkoznak a közbeszerzési eljárás folyamatával. Eltérő véleményekkel találkoztam ugyanis. Az a kolléga, akinek a feladata a közbeszerzési eljárás elejéhez köthető, alapvetően helyesnek és hatékonynak ítéli a közbeszerzési rendszert hazánkban. Az ő feladata a közbeszerzési felhívások figyelése a Közbeszerzési Értesítőben, továbbá a pályázati anyag összeállítása és határidőben történö leadása. Elöljáróban el kell mondani, hogy ez a cég az építőiparban érdekelt és évente kb. 20 közbeszerzési eljárásban vesz részt. Alapvetően hatékonynak tartja a közbeszerzési rendszert, szerinte a kiúrásoknál kellő szigorúsággal és számos feltételt meghatározva teszi meg a felhívást a kíró. Szerinte igen sok feltételnek kell megfelelni és dokumentumot benyújtani ahhoz, hogy egyáltalán pályázhasson valaki. Így nem könnyü bejutni, de ezzel jól megszürhetőek azok, akik amúgy sem tudnának szerződésszerüen teljesíteni. Így létrejött egy kör, amely megbízható, referenciákkal rendelkezik és így az ár mellett a legfontosabb tényező, a minőség is garantálható. Egyre több kiíró fogalmazza meg pontosan az elvárt eredményt, és így még kisebb a lehetőség a minőség romlására. Például a kíró pontosan megnevezi a gépeket, termékeket és anyagokat, így a pályázatban nincs lehetőség azokat olcsóbb és sokszor rosszabb minőségüvel helyettesíteni. Ebből az következik, hogy az összes benyújtott pályázat anyagdíjának közel egyformának kell lennie, és így már csak a munkadíjak lehetnek eltéröek. A munkadíj meghatározása pedig teljesen szuverén. Megoldandó problémaként emelte ki a megkövetelt referenciákkal kapcsolatos helyzetet. Tapasztalatai egybeesnek az én megfigyeléseimmel is, miszerint a kiírók sokszor olyan referenciákat követelnek meg, ami indokolatlan. Például nagyon sokszor adott földrajzi területre vonatkozó referenciákkal kell rendelkezni, vagy túl nagy értékü referenciát kell csatolni. Ehhez kapcsolódóan nehézségként tapasztaltam, hogy egy kisvállalkozó alapvetően nem is tud ezeken a pályázatokon részt venni. A nagy értékü referencia megkövetelésével nem lenne gond, ha az indokolt lenne. Azonban több kiírásban megtalálható az, hogy közel olyan értékű referenciát kérnek, mint maga az egész beruházás.

Összességében elmondható, hogy a kolléga szerint a magyar közbeszerzési rendszer azon szegmensével, amivel ő foglalkozik, nincsen nagyobb probléma. A kolléga kb. négy éve foglalkozik a cég közbeszerzéseivel.

A cég közbeszerzési ügyeivel foglalkozó másik személyt is megfigyeltem, illetve egy rövid interjút készítettem vele. Történetesen a cégvezetőről van szó. Fontos ezt kiemelni, mert ő már az egész folyamatra rálát és alapvetően ő követi nyomon az eseményeket a pályázatbontástól. Néhány esetben már korábbról. Az ő véleménye azonban nem cseng egybe az előbb bemutatottakkal. Az is előfordult, hogy egy közbeszerzési felhívás esetén egyből megkérdezték a kiírót, hogy érdemes-e egyáltalán pályázni. Volt olyan eset, amikor azt a választ kapták, hogy nem. Másik érdekes problémakör az, hogy egyre kevesebb a kiírt pályázat, és így egy pályázatra szinte hatványozódik azok száma, akik pályáznak. Ezt alapvetően a Közbeszerzési Értesítő folyamatos karcsúbbá válásán is lehet látni. Sokszor maguk a gyártók is pályáznak (ami idáig nem volt bevett szokás) és így az ő áraikkal szemben nem lehet versenyképes árat ajánlani. Így olcsóbb lesz a közbeszerzés a jelenlegi gazdasági helyzet miatt. Ezzel azonban szembe helyezhető, hogy a kisvállalkozók nem kapnak munkát, így az ő talpon maradásuk is veszélybe kerül. Feltehető az a kérdés, hogy mikor hatékonyabb egy közbeszerzés, amikor egy nagy multi, gyártó cég miatt olcsóbb az államnak a közbeszerzés, vagy amikor a hazai magyar vállalkozók boldogulnak a piacon? Azt gondolom, hogy ez a gondolat megéri, hogy néhány percig elgondolkodjunk rajta, és egy kicsit a jövőbe látva megértsük a problémát.

Nem feltétlenül tudnám eldönteni ezt a problémát. Mindkét szemszögből tudnék meggyőző érvet felhozni. Lássuk csak, a gazdasági helyzetnek és magának a közbeszerzés hatékonyságát bírálók táborának megnyugtató helyzetnek tünik, ha a közbeszerzés relatíve olcsóbb. Azonban 
hosszabb távon mindenképpen azzal a problémával kell szembenézni, hogy a kisebb, magyar vállalkozók teljesen kiszorulnak a közbeszerzés területéröl, ami számukra amúgy is nehezen megközelíthető. Továbbá elmondandó az a tény is, hogy a magyar vállalkozók egy része alapvetően az elnyert közbeszerzési eljárásokból tartja fenn magát. Így tehát a talpon maradásuk a tét. Közhellyel szólva, itt a lét a tét. Jogász bensőm persze mondatja velem, hogy a közbeszerzés hatékony müködése a legfontosabb. De továbbra is az a nagy kérdés, hogy mi az, hogy hatékony. A 22-es csapdájából kimutatva néhány építőipar sajátosságra hívnám fel a figyelmet.

A jelenlegi gazdasági helyzet kínálta lehetőségeket legjobban a nagy, tőkeerős cégek tudják kihasználni. A közbeszerzési eljárásokon nagy számban olyan pályázók tudnak csak elindulni, amelyek kellően alacsony áron tudnak eredményt nyújtani. A közbeszerzés több szektora közül talán kiemelkedően az építőiparra igaz ez. Magában az építőiparban ugyanis jellemző a több réteg egyidejü megjelenése. Értem ezalatt, hogy a vállalkozók és az alvállalkozók kapcsolata a piramis szerkezetéhez hasonlóan épül fel. Mindenki függ a másiktól, szoros a kapcsolat közöttük. Az építőipar nagyon speciális közbeszerzési területnek számít. A közbeszerzések legnagyobb számban ezen a területen fordulnak elö. Speciálisnak tekinthető abból a szempontból is, hogy rendkívül nagy összegü beruházásokról van. Speciálisnak tekinthető még abból a szempontból is, hogy az építöiparon belül több terület kapcsolódik össze. Az építkezés törvényszerüségei alapján, nemcsak - lesarkítva - a téglák egymásra rakásából áll, hanem számos más tevékenységből is, például nyílászárók gyártása, beépítése, akár külön bontva ablakok és beltéri ajtók, tüzgátlóajtók, forgóajtók. Ilyen tevékenység még a festés, víz-, villany-, gázszerelés, a riasztó és klíma beszerelés, a lámpatestek, szaniterek beszállítása, a padlóburkolat lerakása és így tovább. A sor végtelennek tünik, ha jobban belegondolunk. Ezek alapján jól látható, hogy számos terület kapcsolódik össze, így a legnagyobb specialitása az építőiparnak az, hogy a pályázatot megnyert cégnek igen sok alvállalkozóval kell együttmüködnie, hogy a beruházás megvalósuljon. Minden alvállalkozónak van egy anyagdíja és van egy munkadíja, és ezek szépen összekapcsolódva egy láncot alkotnak. Hasonlóan egy hübéri lánchoz, mindenki függ mindenkitől, de leginkább a láncban alatta lévőtől. Ha az egyik alvállalkozó nem teljesít megfelelöen vagy határidőre, akkor borul a rendszer. Ugyanez történik, ha a kifizetéssel csúszik meg valaki.

Visszakanyarodva az interjúhoz, a megfigyeléseim alapján és az interjúalany szerint is már a kírás szakaszában találkozhatunk visszásságokkal. Nagyon sok pályázat személyre szabottan van kiírva, szinte csak az nincs odaírva, hogy kinek szól. Annyira speciális referenciát kérnek a pályázóktól, ami csak egynek lehet. Például x összegü uszoda felújítás y régióban. Teljesíthetetlen feltétel.

Visszaélés gyakran tapasztalható az ajánlati ár benyújtásánál is. Előfordul, hogy tudatosan a pótmunkára játszanak. A pályázó nyomott áron tudja beadni az ajánlatát, így megnyeri és a későbbiekben pótmunkákkal elvégzi a feladatot, persze nem ingyen. Általános tendencia, hogy az elszámolást a felek között senki nem ellenőrzi. Sajnos korrupt magatartással találkozhatunk az ajánlatok felbontásánál is, még mindig klasszikusnak számít a lapcserézés. Ha azonban valaki kenyértörésre vinni az esetet, az biztos lehet abban, hogy többet nem fog pályázatot elnyerni ott. Szintén az ellenőrzés hiányosságára vezethető vissza az, hogy a pályázó beleírja, hogy nincs alvállalkozója, aki $10 \%$-nál nagyobb részesedésű lenne, majd mégis olyannal végezteti el a munkát. Fontos lenne, hogy ezt ellenőrizzék, mert ez egy tágas jogi kiskapu a közbeszerzés kerítésén.

A feltett kérdésemre, hogy hogyan lehetne hatékonyabbá tenni a közbeszerzési rendszert, a következő nagyon tetszetős megoldásokat kínáló válaszokat kaptam. Először is jogszabályban 
rögzíteni kellene a részpontszámok kiosztásának maximumát. Én is találkoztam már olyan esettel, amikor a pályázó azzal nyerte meg a közbeszerzési pályázatot, hogy garanciális időnek ezer évet adott meg, és így nagyon magas lett ez a részpontszáma. Másodsorban valamilyen megoldást kellene arra vonatkozóan kitalálni, hogy hogyan lehetne előzetesen egy tervezői költségvetést készíteni, amiből világosan kiderül, hogy mennyi alatt nem hozható ki az adott beruházás. Így kizárhatóak lennének azok, akik a pótmunkára apellálnak, illetve más trükköt eszeltek ki.

Érdekes és megdöbbentő beszélgetések voltak ezek. Ismét megerösítést kapott az a feltevésem, hogy a korrupció hol teljes nyíltsággal, hol rejtett formában jelenik meg a mai magyar közbeszerzésben. Számomra igazán izgalmas ez a terület, hiszen nem csak elméleti oldalból vizsgálható, hanem a gyakorlatban is fontos szerepe van. A közbeszerzési eljárás napjainkban az egyik legmeghatározóbb szerződési forma. Egy átlagember számára felfoghatatlanul hatalmas pénzösszegek cserélnek gazdát „egyik napról a másikra”. Éppen ezért is nagyon fontos, hogy a közbeszerzési eljárás szabályai precízen le legyenek fektetve. Ne legyen lehetőség kijátszani a szabályokat, ne legyen lehetőség semmibe venni azokat. Igyekszem minden fórumon megragadni a lehetőséget - így itt is -, hogy felhívjam arra a figyelmet, hogy a közbeszerzési eljárások tisztaságával kapcsolatban komoly aggályok merülnek fel.

A közszolgáltatások nagy része így vagy úgy közbeszerzések révén valósul meg. Közszolgáltatás például egy kórház megléte, de hogy mit is találunk egy kórház belsejében az főleg közbeszerzések révén került oda. Például a gépek, számítástechnikai eszközök, kötszerek és akár a kórház biztonsági szolgálata is.

A Közbeszerzési törvényben nagyon szépen, hangzatosan fogalmazódnak meg az alapelvek. Elgondolkodtató, hogy mennyire valósulnak meg ezek az elvül tüzött célok. A közbeszerzésben helyet kapó korrupció megjelenésének az oka, hogy ezek a hangzatos elvek sok esetben csupán elvek maradnak. Így például a verseny tisztasága oly sok esetben megkérdőjelezhető. Hogy mit is foglal magába a verseny tisztasága? A verseny tisztasága mindenképpen jelenti azt, hogy a felek egyenlő esélyekkel indulhatnak a versenyben. Illetve jelenti azt is, hogy legyen valós verseny. Az, hogy a felek egyenlő eséllyel induljanak egy közbeszerzési eljárásban majdnem kizárt. Alapvetően azért, mert emberek vagyunk, és nem tudunk elvonatkoztatni dolgoktól. Értem ez alatt, hogy a közbeszerzés egy-egy területén a pályázó felek ismerik egymást. Az egyik cég jól ismeri a másikat és a korábbi tevékenységét is. A cégek tudják egymásról, hogy esetleg egy korábbi közbeszerzési eljárásban ki hogyan teljesített. A végrehajtás kapcsán is tudnak a másik tevékenységéről. A megrendelő is tisztában van azzal, hogy kik a pályázó cégek, vannak korábbi tapasztalataik. Söt a közbeszerzési eljárások előtti időkből is vannak tapasztalataik, ami igencsak meghatározza a megrendelő gondolkodásmódját.

Az elvek nem valósulnak meg maradéktalanul. Erre bizonyítékul hozható fel az a tény, hogy a közbeszerzési eljárásokban ritkán győz a legalacsonyabb árat kérő. Általában ez csak egy szempont a többi közül. Gyakran írnak ki pályázatot valakinek úgy névre szólóan, hogy egy olyan referenciával kell rendelkezni, ami biztos, hogy csak neki van. Így ha nem is ő kínálja a legalacsonyabb árat, akkor is nyerni fog. Az ár kialakulását a versenypiacon a kereslet-kínálat határozza meg. A kereslet-kínálat és az ár szoros kölcsönhatásban vannak egymással. Normál esetben ha árcsökkenés van, akkor az keresletnövekedéssel jár együtt. Ha nő az ár, akkor keresletcsökkenés lesz. Egyedi esetekben, ún. presztízsjavak esetén az ár csökkenése mennyiségi csökkenéssel jár, míg létszükségleti javak esetében az ár növekedése keresletnövekedéssel járhat. [6] A versenytársak egyenlő esélyekkel való indulása illetve jelenléte meghatározó az ár alakulásánál. A konkurencia megjelenése kínálatnövekedéssel jár, 
így ez befolyásolja az árak alakulását a piacon, és így a közbeszerzési eljárásban is. Az ajánlati ár benyújtásánál a versenyzök költségeken kívül a haszonnal is számolnak. Leegyszerüsítve: ár = költség + haszon. Vannak olyan pályázatok, ahol alig van verseny, vagy egyáltalán nincs. Ilyen helyzetben több lehetőség adódik a haszonkulcs növelésére, mint akkor, amikor kemény a verseny.[7] Így a megrendelők is kiszolgáltatottabb helyzetbe kerülnek, hiszen a pályázó fél sokkal több profitot szeretne elérni. Így válik egyre drágábbá a közbeszerzés. De - mint ahogy korábban bemutattam az egyik dilemmámat - egy egészen új jelenséggel is találkozhatunk ma már. Alapvetően olcsóbb a közbeszerzés, mert a gyártók árai alá menni képtelenség. Ha valamelyik cég mégis nagyon olcsó anyagdíjat adna meg, akkor alapvetően haszna nem lesz az adott beruházáson. Ez ismét a vállalkozó talpon maradását firtatja.

A közbeszerzés ellentmondásainál meg kell említeni, hogy a korrupción kívül más problémák is vannak. Ilyen például az, hogy a jogérvényesítésre kicsi az esélyük a pályázóknak, és az eljárás nyilvánosságával kapcsolatban is figyelhetők meg nehézségek. A kiírásnál meglévő értékelési szempontokhoz kapcsolt súlyszámokkal való „,visszaélés” is komoly visszássága az közbeszerzési eljárás alapvető céljának. A közbeszerzési eljárásnak két alapvető célja van. Az egyik az lenne, hogy a pályázók egyenlő esélyekkel induljanak. A kisebb cégek is versenybe tudjanak szállni a nagyobb cégekkel szemben. Ez normál esetben - értem ezalatt a közbeszerzés nélküli versenyt- teljesen kizárt. A kisebb cégek nem tudják felvenni a versenyt a nagy, tőkeerős multikkal. Azok a cégek, amelyek kellő anyagi feltételekkel rendelkeznek, könnyedén ki tudják szorítani a kisebb vállalkozásokat. Ezzel pedig a verseny lesz kisebb a különböző vállalkozások között. Mindannyiunk érdeke pedig az lenne, hogy a verseny müködjön, mert ösztökéli a cégeket - legyenek azok akár nagyok vagy kicsik -, hogy minél olcsóbban, minél jobb minőségü terméket illetve szolgáltatást állítsanak elő, hozzanak forgalomba vagy nyújtsanak a fogyasztóknak.

A közbeszerzési eljárásban a másik alapvető cél az, hogy az egész eljárást olcsóbbá tegyék. Olcsóbbá tegyék, mind a pályáztatási eljárást, mind a kivitelezést. Ez az egyik oka annak is, hogy a kiírók általában elbírálási szempontként a legolcsóbb árat veszik figyelembe. Az olcsóság nagyon fontos szempont bárki számára. Senki nem szeret sokat fizetni. Az olcsóság mellett azonban szót kell ejteni a megfelelö müszaki, technikai szintről. Az olcsóság gyakran együtt jár egy sokkal gyengébb minőséggel. A legegyszerübb példáért nem kell messzire menni. Nézzük csak meg a ruhapiacot. A jó minőségü ruhák drágák. Persze relatív, hogy kinek mi a drága, de mondjuk egy teljesen átlagos négyfős család számára, ahol szerencsés esetben mindkét szülő dolgozik. A rosszabb minőségű ruhák, például a kínai import, mindig olcsóbbak lesznek. Ezek mögött persze más dolgok is meghúzódnak. A legkirívóbb eset az, hogy a jó minőségü termékként árult ruhát szintén Kínából exportálják, csak éppen egy jól csengő márka alatt fut. Az ember gyakran találkozik márkás ruhákon azzal a felirattal például, hogy made in Taiwan. Az építőiparban hasonló ez a jelenség. Nem teljesen ugyanerröl van szó, de majdnem. Az építőiparban nem mindig a konszignációban kiírt anyagok kerülnek beépítésre. Sok terméket, anyagot helyettesítenek egy másik, olcsóbbal. Ezzel mindaddig nem is lenne probléma, ha hasonló minőségü anyagról lenne szó. Persze az is előfordulhat, hogy a szerkezet ugyanaz, de több gyártó is készíti és így különbözőek az árak. Söt, ha az egyik építtető mindig ugyanattól a gyártótól rendel és persze nagytételben, akkor természetesen kedvezményt kap, és így még olcsóbban jut a kívánt termékhez. A baj azonban akkor van, ha még csak nem is hasonló a minőségük. Egy konszignációban megadott elemeknél már az árajánlatban is eltérnek. Van persze olyan eset, amikor ez megengedett, de ez nem mindig van így. Ha az árajánlatot bekérő nem veszi észre, hogy ő másra kapta az árajánlatot, mint amire kérte, és megrendeli, akkor már nagy eséllyel az kerül beépítésre, ami az árajánlatban szerepel. Hasonló termékeket gyártó cégek gyakran hasonló elnevezéssel illetik termékeiket, 
ez még nehezebbé teszi a felismerést. Ha nincs szakember, aki ezen hiba lehetőségeket felmérje, súlyos gondok adódhatnak. A laikus emberek számára is köztudott az a tény, hogy jól meg kell nézni, hogy mit építenek be. Az építöipar kifejezetten az a terület, hogy könnyen eltüntethetö, hogy miből is készült. Sajnos sokan vannak a piacon, akik kifejezetten arra játszanak rá, hogy a megrendelö tudatlan.

Az olcsóságra visszatérve. A legalacsonyabb árat ajánló pályázat veszélyes lehet és a közbeszerzés végére kiderülhet, hogy nem a legolcsóbb a legolcsóbb. Az ilyen pályázatoknál gyakori probléma az is, hogy a beszállító nem megbízható. Ajánlott egy alacsony árat, de nem kalkulálta bele a piaci változásokat. Ennek következtében a cég meggyengül, könnyen tönkre mehet, mert az ajánlati kötöttség köti a nyertes pályázót. Ha gazdasági problémái vannak egy cégnek, akkor pedig nem fogja tudni teljesíteni a szerződésben vállaltakat. Ha egy kiíró a legalacsonyabb árat ajánlóval köt szerződést, akkor lehet, hogy a minőséget kockáztatja. A minőség pedig fontos. Mi, átlag fogyasztók betérve ebbe a pályázatot kiíró intézménybe joggal várnánk el a legmagasabb szintü szolgáltatást.

Az építőiparban van még egy nagyon speciális jelenség, a körbetartozás. Ennek a lényege az, hogy az egyes alvállalkozók folyamatosan tartoznak valakinek, akinek szintén tartozik valaki. Ez a rendszer szinte nyomon követhetetlen, viszont a kisebb vállalkozók müködését teljesen ellehetetleníti a piacon. Amíg neki tartoznak, nem tud új projektet elvállalni, a bírósági döntésre pedig akár éveket is várni kell, arról nem is beszélve, hogy lehet, hogy nem is jut a pénzéhez. A közelmúltban azonban érezhető valamelyest a változtatási szándék a törvényhozón, hiszen felmerült annak a lehetösége, hogy az ilyen jellegü pereket a bíróságok soron kívül tárgyalják. Ezek a perek eddig akár évekig is elhúzódhattak, és a vállalkozó bottal üthette a nyomát a pénzének. Konkrét esetben történt meg, hogy egy alvállalkozóval végeztették volna el a munkát, de az előleg átutalásakor eltűnt a pénzzel együtt, persze a munkát el sem kezdve. A cég megtette a feljelentést, és mire egyáltalán ügy lett belöle, két másik vállalkozóval is megtette ugyanezt. A mai napig nem született döntés az ügyében, és persze semmilyen ingósága vagy ingatlanja nincs az egykori alvállalkozó-jelöltnek. Az alvállalkozó megválasztásánál még fokozottabban résen kell lenni, mert könnyen ilyen helyzetben találhatja magát a nyertes pályázó. Nincs elvégezve a munka, ezért őt beperelheti a kíró. A vállalkozó elbukta az előleget, és a saját költségén gyorsan keresnie kell egy másik alvállalkozót, aki - természetesen- a sürgősségre tekintettel némi felárért elvállalja a munkát. A nyertes vállalkozónak lehet, hogy egy ilyen malör miatt veszteséges lesz a megnyert pályázata.

A jogorvoslat lehetősége tehát alapvetően biztosított, de több probléma is felmerül a gyakorlatban. Például abban az esetben, ha valamelyik pályázó szabálytalanságot vesz észre és megteszi a hivatalos lépéseket, az már biztos lehet abban, hogy a következő pályázatra meg sem hívják. Ezért inkább mindenki szemet huny a jogtalanságok felett. Emiatt azonban szinte felmérhetetlen, hogy pontosan mennyi szabálytalanság történik Magyarországon a közbeszerzési eljárásokban, sok a látens jogtalanság.

A jogorvoslati és az ellenőrzés hatékonyságának hiánya miatt számos esetben találkozunk még anomáliákkal. Magyarországon éves szinten extrém méreteket ölt a jogorvoslati eljárások száma. „A verseny megszokott részévé vált, hogy a vesztes ajánlattevők automatikusan jogorvoslati eljárást kezdeményeznek, hiszen egy 100 millió forintos megbízás reményében nem oszt, nem szoroz a (beszerzés tárgyától és értékétől függően) 150-190 ezer forintos eljárási díj."'[8] Ezzel azonban többletköltségeket okoznak a kiíróknak, a határidök is eltolódnak és egyéb kellemetlenségeket szül ez a helyzet.

A megfigyelt cégnél nemrégiben volt egy jogorvoslati eljárás egy olyan kiírt meghívásos eljárásban, amelyen ők is meghívott pályázók voltak. Adott ügy estében az egyik vesztes fél 
jogorvoslati eljárást kezdeményezett arra hivatkozva, hogy túl alacsony az ár, amivel megnyerte a nyertes cég a pályázatot. A jogorvoslati eljárás keretében megállapításra került, hogy jogos a felhozott érv, így új közbeszerzési eljárás kiírására kötelezték a kiíró önkormányzatot. Ez alapvetően kiemelkedően fontos esetnek számít, mert a gyakorlat azt mutatja, hogy ritkán kerül sor ilyen súlyú következményre. Az éremnek, mint mindig, itt is két oldala van. Nagyon helyesnek tartom, hogy egy ilyen példás döntéssel elejét lehetett venni egy korrupt közbeszerzésnek. Azonban azt is látni kell, hogy az adott létesítmény nem épül meg időben, a lakosság nem tudja használni, az újrapályázó vállalkozóknál újabb pályázati költségek merülnek fel, az esetleges elnyert támogatások felhasználása határidőhöz kötött és így eleshetnek tőle. A cégnek újra el kell készíteni az ajánlati árat, mert az eltelt idő alatt változnak az anyagárak is. Sok gyártó cég a konszignáció alapján megajánlott árajánlatát csak pár hétig tartja, illetve az euró mozgásától teszi függővé. Ha ezek a tényezők mind negatív irányba hatnak, akkor jelentős mértékben befolyásolják a korábbi ajánlati árat.

A kisvállalkozók piacra jutásának esélyeinek vizsgálata az egyik részterülete a kutatásomnak. Ezen a területen a hipotézis az, hogy a törvény egyenlő esélyt biztosít mindenki számára. Ez a hipotézis megcáfolható. A kisvállalkozók piacra jutása a közbeszerzések kapcsán igencsak nehéz. A pályázatok elbírálásánál kiemelt fontossággal bír a referenciák megléte. A kisebb vállalkozások esetében kevesebb és kisebb értékủ referenciák megléte tapasztalható. Így egy komolyabb pályázatnál ki vannak zárva. Ez valahol jó is azonban, hiszen egy szerződés teljesítéséhez komoly tőkére van szükség. Megfelelő pénzösszeg hiányában könnyen előfordulhat, hogy a szerződés végrehajtása közben belebuknak.

Megállapítható, hogy a Közbeszerzési törvény nem kifejezetten a kisvállalkozók részvételét támogatja. Sokkal inkább a tőkebiztos vállalkozásokat. Ez azonban ellentétes a Közbeszerzési törvény egyik alapelvével, miszerint egyenlő esélyekkel kell biztosítani a résztvevő feleknek. A magyar kisvállalkozóknak a hazai közbeszerzési eljárásokra olyan nehéz bejutniuk, mint korábban bármely vállalatnak az Európai Uniós pályázatokra. A Magyar Köztársaság és az Európai Közösségek Társulási Megállapodása alapján Magyarország 1994 óta nemzeti elbánást élvez a tagállamok közbeszerzési eljárásaiban. A magyar vállalkozók a tagállamok vállalataival azonos feltételekkel vehetnek részt a tagállamokban kiírt közbeszerzési pályázatokon, ugyanakkor a Társulási Megállapodás e cikke alapján Magyarország 10 éven keresztül nem volt köteles hasonló elbánást nyújtani a más tagállami pályázóknak. A hatályos törvényben azonban már benne van a nemzeti elbánás elve (3. §). Az Európai Unióban a közbeszerzésekkel odaítélendő összegeket a tagállamok korábban igyekeztek saját, hazai vállalataik között szétosztani úgy, hogy a helyi cégek nyerjék el a legtöbb megrendelést. Gazdasági és politikai okokból sokszor még annak ellenére is a hazai vállalatok nyerték el a szerződést, ha árban vagy minőségben gyengébb ajánlatot tettek más tagállamokból érkező versenytársaiknál. A '70-es évektől az Európai Közösség megpróbálta a közbeszerzést is az egységes piac szellemében szabályozni. A Fehér Könyvben - amelynek célja az egységes belső piac megvalósítása - már a közbeszerzési irányelvek nem kizárólag a kormányzati, hanem a közüzemi beszerzésekre is vonatkoztak, valamint szabályozták a közbeszerzésekhez kapcsolható jogorvoslati lehetőségeket. Az uniós tagállamokban közösségi szinten kötelező az állami megrendelések közbeszerzési pályáztatásának és a tenderfelhívásoknak a publikálása. Az esélyegyenlőség betartását az Európai Bizottság ellenőrzi. Az Európai Unió közbeszerzési tenderein a magyar vállalkozók kihasználhatják az olcsónak számító ár- és béradottságaikat, más pályázókkal szemben.

Magyarországon az esélyegyenlőség betartásának figyelése nem megfelelő. Nálunk is sokszor fordul elő, hogy egy kisvállalkozó referencia hiány miatt nem nyeri el a pályázatot, holott kedvezőbb árat tud vállalni. Lehet érvelni amellett, hogy ez biztonságos, mert így ki lehet zárni a nem komoly versenyzőket. De cáfolni is lehet, hiszen az esélyt mindenkinek meg kell 
adni, hogy bizonyítson. A kisvállalkozások gyakran úgy járnak, mint a fiatal pályakezdők, hogy gyakorlatot várnak tölük, de mindenhová csak gyakorlattal rendelkezőt vesznek fel. A közbeszerzésnél pedig referenciával rendelkezőket „várnak”, de a referencia megszerzésére az esély kicsi. A kisvállalkozók az esélyeiket javíthatják, ha elöször kisebb értékü közbeszerzéseknél próbálkoznak, ahol nem követelnek meg nagy összegü referenciát. A pályázat kiírójának is oda kellene erre figyelni. Továbbra is baj az, hogy a pályázat kiírói sincsenek mindig tisztában a kiírás szabályaival. Gyakran követelnek olyan anyagokat, nem csak referenciákat, hanem iratokat, igazolásokat is, amelyekre az eljárás és a szerződés tekintetében nincs szükség.

A kisvállalkozók számára az is megoldást jelenhet, ha alvállalkozóként csatlakoznak a nyertes vállalkozóhoz. Így referenciához is könnyebben juthatnak. Igaz a nyertes vállalkozó nem minden esetben szeret közel engedni mást is a húsosfazékhoz, de a hatalmas beruházásoknál (pl. autópálya építés) szüksége van az alvállalkozókra.

Az Európai Unió a kis- és középvállalkozások közbeszerzésekben való részvételét tovább segíti. A Bizottság a közbeszerzésre vonatkozó állásfoglalásában egy átfogó és összehangolt megközelítést alkalmaz. A stratégia biztosítja többek között az információhoz való hozzáférés feltételeinek javítását az információs és kommunikációs technológia következetes alkalmazása révén. Ennek alapja az elektronikus eszközökre alapozott információtechnológia, az európai hálózatok kifejezetten a kis- és közepes vállalatok számára biztosított jó minőségü szolgáltatásai, a minősítő rendszerek eddiginél hatékonyabb kölcsönös elfogadása, a meghatározott küszöbök alatti értékeknél alkalmazott általános rendelkezések tisztázása, a vállalkozások együttmüködésének támogatása, valamint a kisvállalkozások nagyberuházásokban való részvételéhez szükséges feltételek megteremtése.[9] Az Európai Unió törekvése követendő példa a magyar szabályozás számára.

Általánosságban megfogalmazható az a kijelentés, hogy a közbeszerzéssel foglalkozó felek nem ismerik kellö részletességgel a szabályozást. Egy közbeszerzési eljárásokkal foglakozó cégnek vagy hivatalnak egyszerre kell ismernie a már hatályos rendelkezéseket és a már nem hatályosakat is, mivel a pályázat kiírásakor még lehet, hogy a régebbi szabályok voltak hatályban. Hosszú törvény, nehezen értelmezhető és igen gyakran módosítják. Továbbá a pályáztatók nincsenek tisztában azzal, hogy mely szabályokat kötelesek betartani és melyeket nem. Nem tudják biztosan, hogy a konkrét rendelkezés vonatkozik-e rájuk vagy sem. Ennek következtében sok és szükségtelen igazolást kérnek be a pályázóktól. Mivel nincsenek tisztában a törvényi szabályozással, ezért inkább mindenféle igazolást bekérnek. Ez nem jó sem a pályázóknak, sem a különböző hivataloknak. A pályázóknak azért nem jó, mert a feleslegesen csatolandó igazolások mind költség és idő. A hivataloknak pedig szintén nem költséghatékony, hogy felesleges eljárásokat kell lefolytatniuk és ennek keretében igazolásokat kiadniuk. Így terhelik például az APEH -et illetve a Cégbíróságot.

Szeretném azonban kihangsúlyozni, hogy a közbeszerzési eljárás alapvetően jó dolog. A közpénzek felhasználása kapcsán célja az, hogy lehetővé tegye az átláthatóságot és versenyeztetést. Fontos azonban kihangsúlyozni, hogy a jelenlegi szabályozás sok sebből vérzik és mielőbbi orvoslásért kiált, hiszen a mi pénzünkről van szó, és lehetőleg a pénzünk, föleg a közpénzek ne valakinek a zsebében landoljanak vagy felesleges helyekre vándoroljanak. Mindannyiunk érdeke továbbá az is, hogy megfelelő jogvédelem kerüljön kidolgozásra. A jogvédelem kapcsán zárásul még kiemelném azt a gondolatot, hogy a közbeszerzések kapcsán csak maga a szerződés folyamata van szabályozva, de a végrehajtásra vonatkozóan nincs kidolgozott joganyag. A magánjog szabályai a maga sajátosságaival nem elegendők. A közbeszerzések kapcsán közpénzek kerülnek felhasználásra, ezért kiemelt fontossággal bír az, hogy az eljárás teljes menete szabályos és szabályozott legyen. A teljes 
eljárásban biztosítandó követelmény a verseny tisztasága és a nyilvánosság. A közmegrendelések megszervezését megfelelően közbeszerzésekkel lehet biztosítani. A piac viszonyaiba be kell helyezni az állami megrendeléseket is. A közbeszerzési eljárásnak sok pozitív eredménye van, de rá kell világítani, hogy számos ellentmondása és anomáliája is van. A közbeszerzési eljárásokkal járó eredmények csak az érem egyik oldala. A szabályozás számos pontján problémák vannak, összességében elmondható, hogy a szabályozás egyenlötlen, hol sok, hol pedig kevés.

Még egy, az építőiparban jelentkező problémára hívnám fel a figyelmet. Alapvetően nem csak az építöiparban jelenik meg, de a megfigyelés során konkrétan itt tapasztaltam. A közbeszerzési eljárások nyilvánosságával van a baj. Üzleti titokra történő hivatkozással nem ismerhető meg a nyertes pályázó teljes pályázati anyaga. Így a vesztes vállalkozók igazából pontosan nem is tudják, hogy mi alapján nyerte meg a nyertes. Amint már írtam, könnyen előfordulhat, hogy a konszignációban kiírt elemek helyett másik típusú elemmel pályázik valaki. Mivel, hogy nem lehet tudni, hogy milyen szerkezettel nyert, így a vesztes pályázók jogorvoslattal sem tudnak élni. Továbbá szintén nem ismerhető meg a nyertes pályázó és a kírró közötti végleges szerződés sem, és ez így újabb konszignációtól való eltérést eredményezhet. A nyertes pályázó lehet, hogy olyan szerződést alkuszik ki magának, amiben már eltérő szerkezetek szerepelnek. Alapvetően megoldható a szerződésmódosítás annyival, hogy a gyártó neve kimarad, és csak az adott szerkezet neve marad. Ez azonban közel sem mondható jogszerünek. Lehet, hogy a többi pályázó fél is tudta volna hasonló áron nyújtani a szolgáltatást. Szintén ehhez kapcsolódik, hogy a pályázók a pályázat benyújtásakor már kifejezetten a pótmunkára apellálnak. Ezek a szerződések sem ismerhetőek meg. A közbeszerzési eljárások végrehajtásának ellenőrzésével komoly problémák vannak. Tőlünk nyugatabbra lévő országokban a nyilvánosság szerepe nagyobb, és „az annak érvényesítéséhez szükséges információáramlás szabadságának realizálása”.[10]

A megfigyelés hozzásegített ahhoz, hogy az építőiparban fellelhető közbeszerzési anomáliákat közvetlenül olyan személyektől halljam, akik nap, mint nap ezzel foglalkoznak. Érdekes volt hallani, hogy a közbeszerzésről kinek mi jut az eszébe. A kollégák segítőkészen fogadták a jelenlétemet és a kérdéseimet. Megfigyelhettem minden szakaszát a közbeszerzési eljárásaiknak, szívesen meséltek eddigi saját és ismerőseik tapasztalatairól. Alapvetően szívesen mesélik el a történeteiket nekem, bár mindig az volt az érzésem, hogy tőlem várják a megoldást. Az ország keleti régiójában, az építőiparban dolgozók mind ismerik egymást. Mindenki tud a másik közbeszerzési és egyéb ügyeiröl. Általános tapasztalatom az, hogy a vállalkozók nem elégedettek a közbeszerzési eljárás jelen helyzetével. Visszaesett a közbeszerzési kiírások száma, és már a vállalkozók azt várják, hogy hátha az év második felében kedvezőbb változás következik be a gazdasági helyzetben, és vastagabb lesz a Közbeszerzési Értesítő.

Megállapítom, hogy a terepkutatás módszere nagyon hasznos a kutatási témám esetében. Olyan összefüggésekre világított rá, amikre pusztán elméleti síkon nem biztos, hogy jutottam volna. Olyan problémákkal és megoldást kínáló lehetőségekkel is találkoztam, amelyek idáig nem jutottak az eszembe. A legnagyobb előnye azonban a terepkutatásnak természetesen az, hogy az az elméleti kör, amivel foglalkozok, megjelenik a gyakorlatban.

A legfontosabb tapasztalatom az, hogy az építőiparban mennyi speciális közbeszerzéshez kapcsolódó visszásság van. Korábbi tapasztalataim alapján is találkoztam már néhánnyal, és azokat meg is írtam, de így még közelebbröl vizsgálva, teljesen más aspektusból látok rájuk. A korábbi egyszegmensű vizsgálódásomból kinyílva most számos új oldal került a látókörömbe és így bővül a kutatásom tárgyköre is. Minél több empíriát kell összegyüjtenem ahhoz, hogy egy igazán jól védhető okfejtést hozzak létre. A dolgozat elején vázolt kutatási 
módszerek alkalmasak a közbeszerzési rendszer vizsgálatára. Úgy gondolom, hogy a megfigyelés módszere az egyik legjobb technika. Vannak gyengeségei a módszernek - mint már említettem a dolgozatom elején -, de ha a kutató megtalálja azt a szük mezsgyét, amin mozoghat, akkor jó és felhasználható eredményeket kap. A közbeszerzés témájában a lehetséges kutatási módszerek együttes alkalmazására van szükség. A megfigyelés technikája csak egy ezek közül.

Összességében megállapíthatom, hogy célravezető a megfigyelés módszere. Kellő tudatossággal és kiegészítve az interjúkészítés technikájával valóságos képet kaptam. A megfigyelés eredményeképpen még több adatot gyüjtöttem be, amelyekkel még jobban alá tudom támasztani az állításaimat. A tudományos megfigyelések alapvetően abban különböznek a hétköznapi megfigyelésektől, hogy tervszerüen és céltudatosan végezzük azokat. Konkrét tervem volt arra vonatkozóan, hogy mire vagyok kíváncsi, de céltudatos is voltam, mert már tudtam, hogy mire szeretném felhasználni a kapott eredményeket. Igyekeztem befolyásmentesen végezni a kutatást, tehát nem a saját véleményem alapján irányítani azt bármennyire is résztvevő megfigyelő voltam. Érdekes módon a kutatás egyik eredménye az lett, hogy ma Magyarországon a közbeszerzés nem mindenki szerint müködik annyira rosszul. Bár én hozzátenném, hogy annyira jól sem.

\section{Felhasznált irodalom}

1. Babbie, Earl [2001]: A társadalomtudományi kutatás gyakorlata, Balassi Kiadó, Budapest.

2. Horváth M. Tamás [2005]: Közmenedzsment, Dialóg Campus Kiadó, Budapest - Pécs.

3. Lukács Andrea és Csányi István [2004]: Közbeszerzési Kézikönyv, Terc Kereskedelmi és Szolgáltató Kft. Szakkönyvkiadó Üzletága, Budapest.

4. Page, Brian [1996]: Az ajánlati ár meghatározása, In: Piac - Verseny - Szerződés, „Helyi demokrácia és újítások" Alapítvány, Budapest.

5. HVG, 2007. augusztus 18., 33. szám

\section{Internetes oldal}

1. www.eu2004.hu

\section{Rövid interjú}

1. Ön hogyan viszonyul a közbeszerzéshez?

2. Melyik közbeszerzési eljárást ismeri a legjobban? / Melyik közbeszerzési eljárási formában pályázik a legtöbbet?

3. Mit gondol, a közbeszerzési eljárásokkal drágább vagy olcsóbb a beszerzés Magyarországon?

4. Mi lehet az oka annak, hogy drága?

5. Mit gondol, hasonló helyzet az Európai Unió többi államában is?

6. Van tapasztalata uniós pályázatokkal kapcsolatban?

7. Mi lehet az oka annak, hogy az emberek negatívan állnak a közbeszerzéshez?

8. Könnyen boldogul a közbeszerzési szabályok értelmezésével?

9. Ha információra volt szüksége, honnan szerezte be azokat?

10. Hatékonynak tartja a magyar közbeszerzési rendszert?

11. Hatékonynak tartja magát a közbeszerzési rendszert?

12. Mit gondol, hogyan lehetne még hatékonyabbá tenni a magyar rendszert?

13. Tapasztalt-e valaha visszásságot az eljárás menetében?

14. Mik voltak azok? Melyik szakaszában az eljárásnak?

[1] Egyetemi tanársegéd, Debreceni Egyetem Állam- és Jogtudományi Kar, Pénzügyi Jog és Közmenedzsment Tanszék 
[2] 2003. CXXIX. törvény

[3] Babbie [2001]: 319. o.

[4] u.o. 320. o.

[5] u.o. 321. o.

[6] Lukács -Csányi [2004]: 13. o.

[7] Page [1996]: 201. o.

[8] HVG, 2007. augusztus 18., 33. szám, 60. o.

[9] http://www.eu2004.hu/index.php?op=kozossegi_politikak\&id=16, 2007. január 23. [10] Horváth [2005]: 204. o. 